\title{
Capital Structure and Profitability of Bangladeshi Firms: A Causal Investigation
}

\author{
Zahid Anowar \\ School of Business Studies, Southeast University, Bangladesh
}

Copyright $(2016$ by authors, all rights reserved. Authors agree that this article remains permanently open access under the terms of the Creative Commons Attribution License 4.0 International License

\begin{abstract}
This study attempts to investigate the relationship between capital structure and profitability for a sample of 40-firm listed on Dhaka Stock Exchange (DSE) during the period of 1998-2013. Granger causality shows that bidirectional causality exists between firm size (FS) and profitability (ROA) in the short run. A large size firm has more scope to make more profit. Bidirectional causality also exists between liquidity and profitability. A more profitable company can uphold better liquidity without depends on external fund. However, unidirectional causality exists between capital structure and liquidity in the short run. This finding indicates liquid firms have less preference for debt in the short run. Moreover, unidirectional causality also exists among profitability to capital structure and firm size to liquidity in the short run. POLS fixed and random effects have been employed to check the relationship between capital structure and profitability and findings confirm that profitability, firm size and liquidity have statistically significant relationship with capital structure.
\end{abstract}

Keywords Capital Structure, Leverage, Profitability, FMOLS, Dhaka Stock Exchange

\section{Introduction}

Capital structure indicates the mode of finance of a firm long term capital using equity, debts, or hybrid securities. It is simply the mixture of equity and debt that is required for a firm to finance its assets. Capital is the source of long term financing for a firm that will be deployed for investment to generate return. This study has a significant focus on the relationship dynamics of capital structure and profitability in the context of Bangladeshi firms. I have very strong suspect in this study that the relationship between capital structure and profitability is casual one rather than that of regression. Finance literature grants lots more attention on the research regarding the capital structure decisions. The optimum level of combination of debt and equity will contribute to organization profitability. The topic holds utmost interest for the academics. However, it's a significant decision for the corporate finance managers. After all, at the end of the financial year managers are going to be evaluated by shareholders in terms of profitability of the firm.

The main goal of corporate finance manager is shareholders wealth maximization. This indicates that managers should minimize cost to ensure optimum amount of return as well as optimum capital structure in order to increase firm value. Capital structure is simply the mixture of debt and equity of a firm. [2] posited that capital structure and profitability are positively related based on his study on Bangladeshi firms. A firm should determine the optimal capital structure that leads firm to the maximization of firm's value. Some of the past studies indicated positive relationship between leverage and firms value [33].Nonetheless, capital structure policy is crucial too in a sense of degree of default and bankruptcy risk and hence impact on return. A firm might think of using more debt on the capital structure as it works as tax shield for firms. However, high amount of debt always leads a firm toward some imperative risk and therefore variability of firm's cash flows. Regardless of strong support for optimum capital structure, in theoretical finance we can't find any theory that has been developed to determine optimum capital structure. Therefore this is important task of corporate managers to identify the factors that influence capital structure as well as firm value. In addition, these factors vary across countries and firm's characteristics i.e. liquidity, firm size, profitability etc. [24], is the pioneer to bring the capital structure issue in light though their theory got more popularity as capital structure irrelevance theory. Thereafter, many researchers have conducted fruitful research in the developed country such as $[32,34]$ and postulated the same findings regarding capital structure and profitability.

More awareness in corporate managers regarding the determinants of capital structure will help them to make more wise decisions. This is quite important to understand the determinants of capital structure both theoretically and empirically. However, it seems to us that it is of interest to understand the determinants of capital structure after the theory of [24].However, there is no one unique theory of 
capital structure and it is only that manager choices and confidence have been considered an important variable in capital structure choice.

Investors have more attention to invest in the Bangladeshi market and as an emerging market this market has tremendous potentiality. So, corporate managers should be more serious regarding the firm's capital structure decisions. Even though a small numbers of researches are focused in Bangladesh on the primary determinants of capital structure such as $[26,18,25$, and 2]. But there is no precise conclusion regarding which factors have significant impact in determining a firm's capital structure. The objective of this paper is to investigate the causal relationship among the variables of liquidity, profitability, firm size and capital structure. This study attempts to find out the significance of causal relationship among the variables and the dimensions of causality. I am optimistic that the relationship dynamics will help the corporate managers to formulate strategies which will help them to maximize their firm's profit. This seemingly obvious capital structure influencing factors in Bangladeshi markets significantly differs from those of well-developed market. The profitability of a firm is very significant because shareholders' interests are involved with this issue. So, finding out how capital structure and profitability are causally related is the key objective of this paper.

The rest of this paper proceeds as follows. Section 2 summarizes the literature on the capital structure. Section 3 describes Methodology of this study, analysis and results are presented in Section 4and section 5 concludes the paper.

\section{Theoretical Discussion}

[24] have the pioneer view on the capital structure and its impact on firm value, even though it is most popular as the capital structure irrelevance theory. However, both theoretical and empirical analyses have been developed to find out the determinants of corporate financing decisions in practice. This research has shed light on the traditional finance theory and encompasses with the trade-off theory, the pecking-order theory, signaling theory and more recently the market timing theory. However, there is no common theory of capital structure and it is not logically sound to expect one [5].

According to [14] the main argument highlighted by trade-off theory is that firm's optimal capital structure results from tradeoff between income tax benefits of debt and bankruptcy costs of debts. The pecking-order theory established by [19] spotlight on the hierarchy in manager financing choices among the debts and equity. Transaction cost arising out of external financing is associated with adverse selection bias which induces managers to have a preference for internal financing, and then new debt and finally new equity financing. However, the market timing theory focuses on managers' decision of issuing equity when the firm's market value relative to book value is high and they will issue debt when the debt market conditions are perceived relatively more favorable (see $18,7,11$ )

Latter, rigorous empirical research has been conducted to test the predictions of these theories [20,23, 3, 4, and 5]. The empirical research is in favor of the theories of capital structure at varying degrees. Nevertheless, a large body of literature recognizes that the confidence bias and mangers behavior pattern is a significant determinant of corporate investment and financing decisions. Psychological studies document that confidence causes people to underestimate risks, to be more certain about predictions and to exaggerate their ability to control events (see [6] for an overview of this area).

Sometimes confident managers overestimate the future cash flows as well as the net present value (NPV) of new projects investment [9]. [8] Develops a theoretical model to study the insinuations of managerial confidence on firms financing decisions. The model shows that overconfident managers are more optimistic and like to choose higher debt levels. Therefore, they issue new debt more often compared to other less confident managers. [13] Test the predictions of managers' overconfidence bias. They find that managerial confidence leads to a preference for internal financing over external finance and sets priority on accessing the capital market fund that is debt over equity. The plausible explanation for the manager bias toward debt financing is that confident managers underestimate the probability of financial distress and therefore take on higher levels of debt than optimal. The higher level of debt utilization leads to higher probability of bankruptcy and higher costs of capital. Hence, in support of this confidence bias we expect a positive relation between manager confidence and leverage.

According to the pecking order theory, firms with high liquidity will borrow fewer funds. The reasonable explanation is that a firm with more current assets is expected to generate more internal cash inflows, which can be used to finance its operating and investments activities. Thus, the relationship between liquidity and leverage is negatively correlated. [30-32] have found that liquidity is negatively related to leverage and it's significant. Additionally trade-off theory suggests a positive relationship between leverage and liquidity. The argument is that a firm with higher liquidity position reflects the greater ability to meet short-term obligation on time. [29] Shows that liquidity has ambiguous effect on the capital structure decisions. The proportion of current assets to current liabilities is chosen as a proxy for liquidity.

According to the pecking-order theory, firms prefer funds from internal sources and low risk bearing debt in case of the large volume of expected investment [18-19]. In fact, to manage the risk of future investments profitable firms will choose to have less current leverage because of overflowing of financing resources. [5] has shown in the US market that more profitable firms have less debt which supports the pecking order theory. However, in this study, I measure firm profitability (PRF) as the operating income before depreciation to total assets. I do expect a negative relation between leverage and profitability, supporting the pecking order theory of capital structure. 


\section{Methodology}

\subsection{Variables and Data}

The data have been collected from annual reports of 40 companies listed in Dhaka Stock Exchange (DSE). Among the 40 companies, 8 of them belongs to the food sector, 12 to the pharmaceutical chemical sector, 12 to textile sector, and the rest are in fuel and power, construction and miscellaneous sectors. The coverage period of data set is from year 1998 to 2013. The variables for this study are listed below.

$$
\begin{aligned}
& \mathrm{y}_{1}: \text { Current Ratio }=\text { Current Assets/Current Liabilities } \\
& \mathrm{x}_{1}: \text { ROA }=\text { Return on Assets: }(\text { Net Income/Total Assets }) \\
& \mathrm{x}_{2}: \text { Firm Size }=\text { Natural log of Total Assets } \\
& \mathrm{x}_{3}: \text { LTD }=\text { Long term Debt Ratio: Long-term } \\
& \text { Debt/Total Assets }
\end{aligned}
$$

\subsection{The Model}

In this paper, I have employed Granger causality test and fully modified least square (FMOLS) to examine the long and short run relationship between CR and other explanatory variables in this study. To test data stationarity, I conducted the widely used unit root tests; LLC's test, Breitung's t-statistic, IPS-W-statistic, ADF-Fisher Chi-square and PP-Fisher Chi-square tests. These tests are followed by Granger causality test which is used to check the short run relationship dynamics among the variables. Finally, to check the robustness this study employed panel regression with fixed and random effect model.

\subsection{Panel Unit Root Testing}

[26-27] developed tests on the assumption of the cross-sectional independence of panel units (except for common time effects). Levin panel unit root test operates under the null of a collective unit root in all the variables in panel against the collective stationarity. The variables properties need to avoid the possibility of spurious regressions. In order to assess the stationarity of the variables, this paper employs five different unit root tests including LLC's test $[26,24,27,28]$

\subsection{Panel Causality Analysis}

Panel-based Granger causality test [25] is employed to investigate short-run dynamic relationships. Such an exercise will provide an understanding of the interactions amongst the variables in the system and will shed light on the directions of the causality. The resulting equations are used in conjunction with panel Granger causality testing.

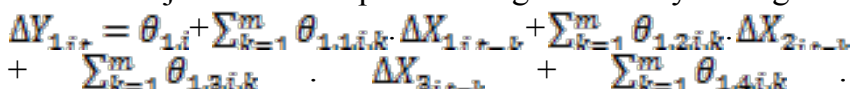

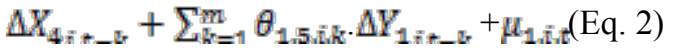

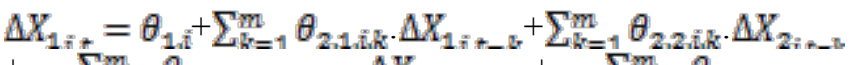

$$
\begin{aligned}
& +\sum_{k=1}^{m} \theta_{2,3, k} \cdot \Delta X_{3 i+-l}+\sum_{k=1}^{m} \theta_{2,4 i k} \text {. } \\
& \Delta X_{4 i+-k}+\sum_{k=1}^{m} \theta_{2,5 i k} \Delta Y_{1 ; i-k}+\mu_{1, i, t}(\text { Eq. 3) } \\
& \Delta X_{2 i t}=\theta_{1, i}+\sum_{k=1}^{m} \theta_{3,1 i k k} \cdot \Delta X_{1 i+-k}+\sum_{k=1}^{m} \theta_{3,2 i k} \text {. } \\
& \Delta X_{2 i t-b}+\sum_{k=1}^{m} \theta_{a, 3 i k} \cdot \Delta X_{3 i t-b}+\sum_{k=1}^{m=1} \theta_{3,4 i k} \text {. }
\end{aligned}
$$

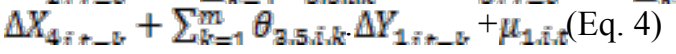

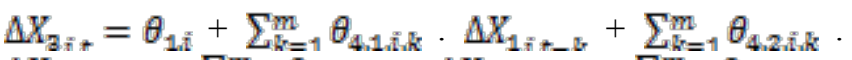

$$
\begin{aligned}
& \Delta X_{2 i+k}+\sum_{k=1}^{m} \theta_{4, a, i k} \cdot \Delta X_{3 i+-b}+\sum_{k=1}^{m} \theta_{4,4, i k} \text {. } \\
& \Delta X_{4 i+-b}+\sum_{k=1}^{m} \theta_{4,5 i k} \cdot \Delta Y_{1 i+-b}+\mu_{1, i, t}(\text { Eq. 5) }
\end{aligned}
$$

\subsection{Panel Least Squares with Fixed and Random Effects}

Panel data allows controlling for variables those cannot observe or measure like cultural factors or difference in business practices across companies; or variables that change over time but not across entities. This is, it accounts for individual heterogeneity. With panel data it can include variables at different levels of analysis suitable for multilevel or hierarchical modeling through the analysis of fixed effects and random effects.

\section{Empirical Results and Discussion}

Table 1. Descriptive Statistics

\begin{tabular}{|ccccc|}
\hline & LTD & FS & CR & ROA \\
Mean & 0.146590 & 20.35351 & 1.412552 & 0.043554 \\
Median & 0.075897 & 20.34163 & 1.198340 & 0.030213 \\
Maximum & 0.903967 & 25.04234 & 7.457085 & 0.429836 \\
Minimum & 0.000000 & 17.09908 & 0.029440 & -0.309730 \\
Std. Dev. & 0.182462 & 1.116188 & 0.831497 & 0.069526 \\
Skewness & 1.624506 & 0.239073 & 2.314970 & 0.073595 \\
Kurtosis & 5.098620 & 3.952679 & 11.58277 & 8.898100 \\
Jarque-Bera & 426.3681 & 32.38232 & 2710.357 & 992.0637 \\
Probability & 0.000000 & 0.000000 & 0.000000 & 0.000000 \\
Sum & 100.2673 & 13921.80 & 966.1858 & 29.79122 \\
Sum Sq. Dev. & 22.73860 & 850.9331 & 472.2173 & 3.301521 \\
Observations & 600 & 600 & 600 & 600 \\
\hline
\end{tabular}

Jarque-Bera statistics and the zero p-values confirm the hypothesis that the data are not following a normal distribution. So, in this study it is obvious that data are not normally distributed. However, the lower mean and median of current ratio (CR) and deviation between max and min value is marginally higher due to major external funding infusion. The mean and median values of LTD ratio also show less deviation. For many firms, the amount reported in the balance sheet as long-term debt is zero which produces a zero debt ratio for these firms. The firm size is normally distributed with zero $p$ value. The mean and median value of the firm size (FS) is consistent with other explanatory variables in this study. The negative ROA minimum value is logical. A firm can have negative return in a particular year. 
Table 2. Panel Unit Root Test Results

\begin{tabular}{ccccc}
\hline Method & CR & ROA & FS & LTD \\
\hline LLC-t* & & & & \\
Level & $3.676(0.99)$ & $-3.902(0.00)^{* *}$ & $-1.895(0.02)^{* *}$ & $-1.010(0.15)$ \\
First difference & $-5.284(0.00)^{* *}$ & $-10.35(0.00)^{* *}$ & $-7.34(0.00)^{* *}$ & $-5.824(0.05)^{* *}$ \\
Breitung- t-stat & & & & \\
$\quad$ Level & $2.996(0.99)$ & $0.489(0.68)$ & $0.965(0.83)$ & $1.434(0.92)$ \\
First difference & $-0.203(0.01)^{* *}$ & $-2.202(0.01)^{* *}$ & $-2.992(0.04)^{* *}$ & $-3.569(0.00)^{* *}$ \\
IPS-W-stat & & & & \\
$\quad$ Level & $-2.528(0.00)$ & $-3.685(0.00)$ & $-38.64(0.00)^{* *}$ & $-0.138(0.44)$ \\
First difference & $-8.085(0.00)^{* *}$ & $-8.833(0.00)^{* *}$ & $-18.44(0.00)^{* *}$ & $-3.592(0.00)^{* *}$ \\
ADF-Fisher & & & & \\
Chi-square & $187.51(0.00)^{* *}$ & $178.49(0.00)^{* *}$ & $145.58(0.04)^{* *}$ & $116.06(0.23)$ \\
$\quad$ Level & $251.90(0.00)^{* *}$ & $274.71(0.00)^{* *}$ & $189.76(0.00)^{* *}$ & $165.36(0.00)^{* *}$ \\
First difference & & & & \\
PP-Fisher Chi-square & & & & \\
$\quad$ Level & $308.10(0.00)^{* *}$ & $209.23(0.00)^{* *}$ & $251.52(0.00)^{* *}$ & $209.24(0.00)^{* *}$ \\
First difference & $561.42(0.00)^{* *}$ & $562.28(0.00)^{* *}$ & $433.13(0.00)^{* *}$ & $442.80(0.00)^{* *}$ \\
\hline
\end{tabular}

Notes: LLC, IPS, ADF-Fisher and PP-Fisher examine the null hypothesis of non-stationarity, and ** indicates statistical significance at the $5 \%$ level. Probabilities for Fisher-type tests were computed by using an asymptotic $\chi 2$ distribution. All other tests assume asymptotic normality. The lag length is selected using the Modified Schwarz Information Criteria.

The unit root tests results show that all the data are stationary either at level or first difference. This is the indication of normality of the data set has used in this study. To avoid any confusion I have gone through all five statistics of the unit root test.

Table 3. Granger Causality Test

\begin{tabular}{lccc}
\hline \multicolumn{1}{c}{ Null Hypothesis: } & Obs & F-Statistic & Prob. \\
\hline FS does not Granger Cause LTD & 633 & 0.02868 & 0.8656 \\
LTD does not Granger Cause FS & & 0.33858 & 0.5609 \\
\hline CR does not Granger Cause LTD & 633 & 2.36460 & 0.1246 \\
LTD does not Granger Cause CR & & 5.63858 & 0.0179 \\
\hline ROA does not Granger Cause LTD & 633 & 4.67852 & 0.0309 \\
LTD does not Granger Cause ROA & & $1.1 \mathrm{E}-05$ & 0.9974 \\
\hline CR does not Granger Cause FS & 637 & 1.52385 & 0.2175 \\
FS does not Granger Cause CR & & 7.27722 & 0.0072 \\
\hline ROA does not Granger Cause FS & 637 & 22.0540 & $3 . \mathrm{E}-06$ \\
FS does not Granger Cause ROA & & 4.32586 & 0.0379 \\
\hline ROA does not Granger Cause CR & 637 & 20.3015 & $8 . \mathrm{E}-06$ \\
CR does not Granger Cause ROA & & 15.8354 & $8 . \mathrm{E}-05$ \\
\hline
\end{tabular}

The Granger causality test results are presented in Table 3 . The results are quite interesting. First, the results indicate that a strong bidirectional causal relationship exists between current ratio (CR) and return on assets (ROA) in the short run. So, it is quite logical that better liquidity position has positive influence on profitability. The bidirectional causal relationship between return on assets (ROA) and firm size (FS) exists in the short run. The large firms have more scope to make more profit rather small size firms. The unidirectional causality exists between capital structures (LTD) and liquidity (CR). The more liquid firms have impact on the capital structure of firms. The liquid firms will have less preference for external debt or equity in the short run. Long term debt offers tax advantages in the firms' cash flows. The unidirectional causal relationship also exists among return on assets (ROA) and capital structure, firm size (FS) and current ratio (CR). The larger firms have more scope to manage fund to maintain the liquidity position. As the large firms are creditworthy and carrying good image in the financial markets. So they can handle any uncertainty in the capital structure. So, capital structure and profitability have unidirectional causal relationship in the short run.

Table 4. Panel Least Squares (fixed effects)

\begin{tabular}{ccccc}
\hline Variable & Coefficient & Std. Error & t-Statistic & Prob. \\
\hline FS & 0.021074 & 0.010141 & 2.077962 & 0.0381 \\
CR & 0.021525 & 0.007635 & 2.819250 & 0.0050 \\
ROA & 0.124834 & 0.000637 & 3.567528 & 0.0015 \\
C & -0.318173 & 0.205770 & -1.546255 & 0.1226 \\
\hline \multicolumn{5}{c}{ Effects Specification } \\
Cross-section fixed & \multicolumn{5}{|}{} \\
Period fixed & \multicolumn{5}{|}{ Mean dependent var } & 0.146590 \\
\hline R-squared & 0.699944 & S.D. dependent var & 0.182462 \\
Adjusted R-squared & 0.668921 & Akaike info criterion & -1.579745 \\
S.E. of regression & 0.104987 & Schwarz criterion & -1.149457 \\
Sum squared resid & 6.822850 & Hannan-Quinn criter. & -1.413236 \\
Log likelihood & 605.2728 & Durbin-Watson stat & 0.949532 \\
F-statistic & 22.56171 & & \\
Prob(F-statistic) & 0.000000 & &
\end{tabular}

POLS is a test of dynamic heterogeneous panel, has been used here to check the robustness of this study. POLS fixed effects test confirms firm size, liquidity and profitability have significant statistical relationship with capital structure. The coefficient value of POLS fixed effect test is quite interesting. The panel regression values of the all explanatory variables are significant that is when profitability is increased by $1 \%$ that will impact by $.124 \%$ of the firm's capital structure. Moreover, if firm size increased by $1 \%$ that will increase the capital structure by $.021 \%$ and the coefficient vale of liquidity shows it has impact on the 
capital structure by $0.021 \%$. Moreover, these findings are in support of pecking-order theory and other empirical findings regarding capital structure theory.

Table 5. Panel Least Squares (Random effects)

\begin{tabular}{ccccc}
\hline Variable & Coefficient & Std. Error & t-Statistic & Prob. \\
\hline FS & -0.011664 & 0.007140 & -1.633620 & 0.1028 \\
CR & 0.017757 & 0.007523 & 2.360471 & 0.0185 \\
ROA & 0.063318 & 0.005118 & 2.800305 & 0.0038 \\
C & 0.355686 & 0.146227 & 2.432428 & 0.0153 \\
\hline \multicolumn{5}{c}{ Effects Specification } \\
\hline Cross-section random & \multicolumn{5}{c}{0.147382} & 0.6621 \\
Period random & \multicolumn{5}{c}{0.000000} & 0.0000 \\
Idiosyncratic random & \multicolumn{5}{c}{0.105294} & 0.3379 \\
\hline \multicolumn{5}{c}{ Weighted Statistics } \\
\hline R-squared & 0.012460 & Mean dependent var & 0.027413 \\
Adjusted R-squared & 0.008116 & S.D. dependent var & 0.107588 \\
S.E. of regression & 0.107151 & Sum squared resid & 7.830252 \\
F-statistic & 2.868289 & Durbin-Watson stat & 0.848334 \\
Prob(F-statistic) & 0.035794 & & \\
\hline
\end{tabular}

The results of POLS random effects results show that profitability and liquidity have significant impact on the firm's capital structure in the study. The findings also indicate firm size relationship with capital structure is not statistically significant. However, the findings of PLOS random effects are consistent in the study compare with other models have been used to test the relationship between capital structure and profitability.

\section{Conclusions and Policy Implication}

This study emphasizes to investigate the relationship between capital structure and profitability. Data have been collected from the financial statements of each firm during period of 1998 to 2013 . The granger causality test shows that bidirectional causal relationship exists between current ratio (CR) and return on assets (ROA) in the short run. So, it is quite logical that better liquidity position has positive influence on profitability. The bidirectional causal relationship also exists between return on assets (ROA) and firm size (FS) in the short run. The large firms have more scope to make more profit rather small size firms. The unidirectional causality exists between capital structures (LTD) and liquidity (CR). The more liquid firms have impact on the capital structure of firms. The liquid firms will have less preference for external debt or equity in the short run. Long term debt offers tax advantages in the firms' cash flows. The unidirectional causal relationship also exists among return on assets (ROA) and capital structure, firm size (FS) and current ratio (CR). Results also reveal that leverage ratios are significantly different across Bangladeshi industries. The findings of POLS show that in the fixed effects test confirms firm size, liquidity and profitability have significant statistical relationship with capital structure. The results of POLS random effects show that profitability and liquidity have significant impact on the firm's capital structure in the study. These findings help me to draw a strong conclusion that capital structure has relationship with profitability, firm size and liquidity. Moreover, these findings are in support of pecking-order theory and other empirical findings regarding capital structure theory. Overall all the results are almost consistent with previous study and capital structure.

This study helps us to show some meaningful insights into the corporate financial management in Bangladesh. The proportion of debt and equity mix in the firm's capital structure is the key concern for managers. This paper finds and supports that evidence. As the relationship between capital structure and profitability is bidirectional in the short run hence it is vital to focus on capital structure more. Moreover, all the variables in this study have significant influence on the capital structure.

\section{REFERENCES}

[1] Alom, K. 2013, Capital Structure Choice of Bangladesh Firms: An Empirical Investigation, Asian Journal of Finance \& Accounting; Vol. 5, No. 1 .

[2] Baker, M. and Wurgler, J., 2002, Market timing and capital structure, Journal of Finance 57, 1-32. http://dx.doi.org/10.1111/1540-6261.00414

[3] Fama, E. and French, K., 2002, Testing trade-off and pecking order predictions about dividends and debt, Review of Financial Studies 15, 1-33. http://dx.doi.org/10.1093/rfs/15.1.1

[4] Frank, M. and Goyal, V., 2003, Testing the pecking order theory of capital structure, Journal of Financial Economics 67, 217-248. http://dx.doi.org/10.1016/S0304-405X(02)00252-0

[5] Frank, M. and Goyal, V., 2004, Capital structure decisions: which factors are reliably important, Working paper, Sauder School of Business, University of British Columbia, Canada.

[6] Gilovich, T., Griffin, D. and Kahneman, D., 2002, Heuristics and biases: The psychology of intuitive judgement, Cambridge University Press, New York, USA. http://dx.doi.org/10.1017/CBO9780511808098

[7] Graham, J. and Harvey, C., 2001. The theory and practice of corporate finance: evidence from the field, Journal of Financial Economics 60, 187-243.

http://dx.doi.org/10.1016/S0304-405X(01)00044-7

[8] Hackbarth, D., 2004, Managerial Traits and Capital Structure Decisions, Working Paper, Finance Department, Kelley School of Business, Indiana University, USA

[9] Heaton, J., 2002, Managerial Optimism and Corporate Finance, Financial Management 31(2), 33-45. http://dx.doi.org/10.2307/3666221 
[10] Hovakimian, A., 2006, Are observed capital structures determined by equity market timing, Journal of Financial and Quantitative Analysis 41(1), 221-248. http://dx.doi.org/10.1017/S0022109000002489

[11] Hovakimian, A., Opler, T. and Titman, S., 2001. The debt-equity choice, Journal of Financial and Quantitative Analysis 36, 1-24. http://dx.doi.org/10.2307/2676195

[12] M. Lima, (2009), "An Insight into the Capital Structure Determinants of the Pharmaceutical Companies in Bangladesh"[Online] Available at: http://www.gbmf.info/20 09/An_insight_into_the_Capital_Structure_Determinants_Li ma.pdf.

[13] Malmendier, U., Tate, G. and Yan, J., 2005, Corporate financial policies with overconfident managers, 8th Annual Texas Finance Festival. Available at SSRN Abstract 895843.

[14] Miller, M., 1977, Debt and taxes, Journal of Finance 32, 261-275.

[15] Modigliani, F. and Miller, M., 1958, The cost of capital, corporation finance and the theory of investment, American Economic Review 53, 261-97.

[16] M. A. Sayeed, "The Determinants of Capital Structure for Selected Bangladeshi Listed Companies", International Review of Business Research Papers, Vol. 7, No. 2, pp. 21-36, 2011.

[17] MU.Chowdhury, "Capital Structure Determinants: Evidence from Japan \& Bangladesh", Journal of Business Studies, vol.xxv, no.1, pp. 23-45, 2004

[18] Myers, S., 1984, The capital structure puzzle, Journal of Finance 39, 575-92. http://dx.doi.org/10.2307/2327916

[19] Myers, S. and Majluf, N., 1984, Corporate financing and investment decisions when firms have information that investors do not have, Journal of Financial Economics 13, 187-221. http://dx.doi.org/10.1016/0304-405X(84)90023-0

[20] Rajan, R. and Zingales, L., 1995, What do we know about capital structure? Some evidence from international data, Journal of Finance 50, 1421-1460. http://dx.doi.org/10.1111/j.1540-6261.1995.tb05184.x

[21] S. Akhtar and B. Oliver, "Determinants of capital structure for Japanese multinational and domestic corporations", International Review of Finance, Vol. 9, pp. 1-26, 2009 http://dx.doi.org/10.1111/j.1468-2443.2009.01083.x

[22] S.P. Chowdhury and A. Chowdhury, "Impact of Capital Structure on Firm's Value: Evidence from Bangladesh", Business and Economic Horizons, Vol. 3, No. 3, pp. 111-122, 2010.

[23] Shyam-Sunder, L. and Myers, S., 1999, Testing static tradeoff against pecking order models of capital structure, Journal of Financial Economics 51, 219-244.http://dx.doi.org/10.1016/ S0304-405X (98)00051-8.

[24] Dickey, D.A., Fuller, W.A. (1979), Distribution of the Estimators for AutoRegressive Time Series with a Unit Root. Journal of the American Statistical Association, 74(366), $427-431$.

[25] Engle, R. F., and Granger, C. W. J. (1987), "Co-Integration and Error Correction: Representation, Estimation, and Testing" Econometrica, 55, (2), 251-276.

[26] Levin, A., Lin, C.F., Chu, C.S. (2002), Unit Root Tests in Panel Data: Asymptotic and Finite-Sample Properties. Journal of Econometrics, 108(1), 1-24.

[27] Pesaran H., Shin, Y., \& Smith, R.,(1999), Pooled Mean Group Estimation of Dynamic Heterogeneous Panels, Journal of the American Statistical Association, 94, 621-634.

[28] Phillips, P.C.B., Perron, P. (1988), Testing for a Unit Root in Time Series Regressions. Biometrika. 75(2), 335-346.

[29] Ozkan, A. 2001. "Determinants of Capital Structure and Adjustment to Long Run Target: Evidence from UK Company Panel Data," Journal of Business Finance \& Accounting, 28, 175-198.

[30] I. Friend and L. H. Lang, "An empirical test of the impact of managerial self-interest on corporate capital structure", The Journal of Finance, Vol. 43, No. 2, pp. 271-281, 1988.

[31] Deesomsak, R. Paudyal and G. Pescetto, "The determinants of capital structure: evidence from the Asia Pacific region", Journal of Multinational Financial Management, 14, 387-405, 2004.

[32] Sbeiti w., The Determinants of Capital Structure: Evidence from the GCC Countries, International Research Journal of Finance and Economics ISSN 1450-2887 Issue 47 (2010) (C) Euro Journals Publishing, Inc. 2010 http://www.eurojournals.com/finance.htm 